\title{
PROBLEMATIKA PELAKSANAAN DIVERSI \\ DALAM PENYIDIKAN PIDANA DENGAN PELAKU ANAK \\ DI KEPOLISIAN RESORT MALANG
}

\author{
Fachrizal Afandi \\ Fakultas Hukum Universitas Brawijaya \\ Jl. MT. Haryono 169 Malang \\ Email: fachrizalafandi@gmail.com
}

\begin{abstract}
Diversion as a new concept in Law 11/2012 on the Juvenile Justice System is becoming problematic in its practices. Several regulations and infrastructures, which obligatoryfor supporting diversionhave not been provideduntil now. This article attempted to see how diversion implementations and its problems during the police investigation.The research has found that the lack of infrastructures and technical regulations on the Law 11/2012 resulted the inefficiency of the diversion implementation.
\end{abstract}

Key words: diversion, investigation, police, juvenille justice system

\begin{abstract}
Abstrak
Sebagai konsep yang sama sekali baru, konsep Diversi dalam Undang-undang Nomor 11 tahun 2012 tentang Sistem Peradilan Pidana anak tidak lepas dari berbagai macam masalah. Berbagai macam aturan pelaksana yang harusnya disiapkan beserta infrastruktur penunjang system diversi dalam waktu 2 (dua) tahun sejak diundangkan ternyata belum semuanya terbangun dengan baik. Penelitian ini mencoba melihat bagaimana praktik pelaksanaan diversi di tahapan penyidikan dengan mengambil focus di Kepolisian Resort Kabupaten Malang (Polres Malang). Penelitian yuridis empiris ini menggunakan metode socio-legal dengan mengkombinasikan isu hukum dan praktik di lapangan ditinjau dari ilmu sosial. Hasil penelitian menunjukkan ketiadaan infrastruktur dan peraturan pelaksana UU SPPA yang mengatur proses diversi mengakibatkan tidak optimalnya pelaksanaan diversi.
\end{abstract}

Kata kunci: diversi, penyidik, polisi, system peradilan pidana anak

\section{Latar Belakang}

Model restorative yang mengutamakan pelaksanakan diversi sebagaimana diamanatkan dalam Undang-undang Nomor 11 tahun 2012 tentang Sistem Peradilan Pidana Anak (UU SPPA) merupakan sistem peradilan pidana berbiaya mahal karena banyaknya infrastruktur baru yang harus disiapkan oleh negara untuk memastikan system peradilan berjalan dengan baik (Fionda,2006).Selain memakai model ini, negara-negara seperti Amerika Serikat dan Inggris lebih memilih 
untuk memodifikasi punitive model dengan pendekatan yang lebih pro terhadap anak. ${ }^{1}$

Seperti Selandia Baru dan Finlandia, Indonesia dengan memberlakukan UU SPPA telah mengambil jalan mengatasi kejahatan dengan pelaku anak dengan memanfaatkan alternative upaya diversi. Hal ini merupakan konsekwensi Indonesia yang telah meratifikasi berbagai macam aturan internasional seperti konvensi Hak Anak (Convention on the Rights of the Child) pada tahun 1990, Beijing Rules, tanggal 29 November 1985, The Tokyo Rules, tanggal 14 Desember 1990, Riyadh Guidelines, tanggal 14 Desember 1990, dan Havana Rules, tanggal 14 Desember $1990 .^{2}$

Secara prinsipil UU SPPA telah menggunakan model restorative justice yang berpusat pada proses diversi sebagai upaya penyelesaian tindak pidana yang dilakukan oleh anak. Penerapan restorative justice diharapkan akan menawarkan jawaban atas isu-isu penting seperti kritik terhadap sistem peradilan pidana yang tidak memberikan kesempatan khususnya bagi korban; menghilangkan konflik khususnya antara pelaku dengan korban dan masyarakat; fakta bahwa perasaan ketidakberdayaan yang dialami sebagai akibat dari tindak pidana harus di atasi untuk mencapai proses pemulihan. ${ }^{3}$

Konsep baru dalam UU SPPA ini dipandang baik utamanya konsep diversi yang menghindarkan anak dari jalur litigasi, dengan beberapa lembaga baru yang dibuat tentunya UU SPPA ini diharapkan konsep restorative justice dapat terlaksana secara efektif. ${ }^{4}$

Sebagai sebuah system, sebagaimana didefinisikan dalam pasal 1 UU SPPA, yang mencakup institusi mulai tahap penyelidikan sampai dengan tahap pembimbingan setelah menjalani pidana, sinergitas antara lembagalembaga yang menopang proses peradilan pidana anak sangatlah penting dan menentukan keberhasilan implementasi model restorative justice ini.

Salah satu problem yuridis yang muncul saat ini adalah, belum adanya peraturan pemerintah sebagaimana diamanatkan UU SPPA yang mengatur tentang pelaksanaan diversi. ${ }^{5}$ Hal yang kemudian tentunya berimbas pada tataran implementasi di lapangan terkait tupoksi dan model koordinasi antar lembaga dalam melaksanakan proses dan hasil kesepakatan diversi dalam system peradilan pidana anak.

1 Barry Goldson and John Muncie, Rethinking Youth Justice: Comparative Analysis, International Human Rights and Research Evidence, 2006, http://yjj.sagepub.com/content/6/2/91.refs.html, diakses 3 September 2014 pukul 09.30 WIB.

2 Sufriadi Pinim \& Erasmus Napitupulu, Studi atas Praktik-praktik Peradilan Anak di Jakarta, Institute for Criminal Justice Reform, Jakarta, 2013, hlm. 72.

3 Taufik Makarao, Pengkajian Hukum tentang Penerapan Restorative Justice dalam Penyelesaian Tindak Pidana yang Dilakukan Oleh Anak-anak, Badan Pembinaan Hukum Nasional, Jakarta, 2013.

4 Yutirsa Yunus, Analisa Konsep Restorative Justice Melalui Sistem Diversi dalam Sistem Peradilan Pidana Anak di Indonesia, Jurnal Rechtsvinding, Volume 2 No. 2, Agustus 2013.

5 Sinar Harapan, Pemerintah Dinilai Abaikan Kepentingan Anak, http://sinarharapan.co/news/ read/140616047/Pemerintah-Dinilai-Abaikan-Kepentingan-Anak, diakses 3 September 2014 pukul 09.00 WIB. 
Berdasarkan focuss group discussion yang dilakukan oleh penulis dengan para penyidik anak Kepolisian Resort Se-Jawa Timur, ditemukan bahwa sebagian besar penyidik anak belum mengetahui mekanisme diversi dan belum ada koordinasi dengan instansi terkait pelaksanaan Diversi. Lembaga yang diamanatkan dalam UU SPPA semisal Lembaga Penyelenggaraan Kesejahteraan Sosial (LPKS) yang seharusnya menjadi tempat untuk melakukan penahanan anak belum terbentuk di daerah-daerah. ${ }^{6}$ Hal ini menjadi kendala serius bagi penyidik yang harus melaksanakan perintah UU SPPA sejak bulan Agustus 2014 ini.

Khusus di Kepolisian Resort Malang, sebagaimana hasil penelitian terdahulu yang dilakukan penulis, kesiapan pelaksanaan diversi untuk kasus anak didukung oleh perhatian serius dari Pemerintah Daerah. ${ }^{7}$ Bentuk keseriusan ini antara lain adalah adanya koordinasi rutin yang diselenggarakan Sekretaris Daerah Pemerintah Kabupaten Malang dalam penanganan kasus anak dan juga alokasi anggaran khusus untuk anak yang sedang menghadapi kasus hukum.

Oleh karenanyaberdasarkan latar belakang di atas, penelitian ini ingin melihat dalam tataran yuridis empiris dengan pendekatan multidisiplin terkait dengan fenomena pemberlakuan UU SPPA yang baru saja dijalankan bulan Agustus 2014 ini beserta beberapa problematika yang dihadapi.Hal ini menurut peneliti penting sebagai assessment awal terhadap efektifitas pemberlakuan diversi di tahapan penyidikan agar dapat dilakukan segera evaluasi regulasi yang tidak pro-anak.

Penelitian ini mencoba fokus pada proses diversi dalam tahap penyidikan di Kepolisian Resort Malangkarena terbatasnya anggaran dan waktu. Tidak adanya spesifikasi jenis tindak pidana yang diteliti disebabkan belum banyaknya penanganan kasus pidana dengan pelaku anak yang ditangani Kepolisian Resort Malang.

Ada 2 (dua) permasalahan yang menjadi fokus perhatian peneliti berkaitan dengan latar belakang yang telah dikemukakan, yaitu 1. Bagaimana implementasi kewajiban diversi dalam kasus pidana dengan pelaku anak dan apa saja problematika yang dihadapi penyidik dalam pelaksanaan diversi di Kepolisian Resort Malang? 2. Langkah strategis apa yang telah atau sedang dilakukan penyidik di Kepolisian Resort Malang untuk mengatasi problem yang muncul terkait dengan pemberlakuan diversi?

Penelitian ini menggunakan pendekatan sosio-legal, yaitu dengan cara melakukan telaah untuk memecahkan problematika

6 Diolah dari hasil angket yang disebarkan kepada 26 penyidik anak di Kepolisian Resort se-Jawa Timur pada acara Workshop IbM penyidik anak dalam melaksanakan diversi berbasis Restorative Justice, 20 Agustus 2014.

7 Laporan Penelitian Hibah Bersaing Institusi Batch II 2012, Desain Pelembagaan Diversi Dalam Perkara Anak Berbasis Social Responsibility (Studi Pada Tiga Kepolisian Resort Kota/Kabupaten di Jawa Timur), Tidak dipublikasikan. 
hukum secara interdsipliner dengan menggunakan/ meminjam teori dari ilmu sosial yang serumpun. ${ }^{8}$

\section{Pembahasan}

\section{A. Kajian tentang Penyidikan Kasus Pidana dengan Pelaku Anak}

Undang-undang Nomor 11 tahun 2012 tentang Sistem Peradilan Pidana Anak memberikan perlakuan istimewa terhadap anak yang berkonflik dengan hukum sejak dari proses penyidikan. Perhatian dan perlakuan khusus tersebut bertujuan agar anak tidak menjadi korban dari penerapan prosedur hukum yang rigid dan formal yang dikuatirkan dapat dapat menyebabkan penderitaan secara mental, fisik dan sosial bagi anak.

Oleh karenanya, terkait dengan anak yang yang dilaporkan melakukan tindak pidana, penyidik wajib merahasiakan identitas sang anak baik dari pemberitaan di media cetak maupun di media elektronik. ${ }^{9}$ Hal ini berkaitan dengan asas praduga tidak bersalah (percumption of innocent) dan juga untuk menghindarkan dampak proses stigmatisasi masyarakat terhadap anak.

Selain itu, UU SPPAjuga telah menyiapkan aparat penegak hukum secara khusus penyidik yang menangani perkara dengan pelaku anak, sebagaimana dikemukakan dalam Pasal 1 butir 8 UU SPPA yang menegaskan bahwa hanya pejabat penyidik khusus anak yang ditetapkan berdasarkan Keputusan Kepala Kepolisian Negara Republik Indonesia atau pejabat lain yang ditunjuk oleh Kepala Kepolisian Negara Republik Indonesia yang dapat melakukan penyidikan terhadap anak yang diduga melakukan tindak pidana tertentu. Syarat untuk dapat ditetapkan sebagai Penyidik Anak diatur dalam Pasal 26 (3) UU SPPA dimana penyidik anak harus berpengalaman sebagai penyidik, mempunyai minat, perhatian, dedikasi, dan memahami masalah anak; dan telah mengikuti pelatihan teknis tentang peradilan Anak.

Dalam melakukan proses penyidikan, penyidik anak secara simpatik harus menciptakan suasana kekeluargaan agar pemeriksaan berjalan dengan lancar tanpa ada rasa ketakutan dari anak yang diproses sehingga anak tersebut mudah untuk mengungkapkan keterangan yang benar dan sejelas-jelasnya. ${ }^{10}$ Selain juga penyidik dilarang menggunakan atribut kedinasan saat penyidikan berlangsung, ${ }^{11}$ hal ini dimaksudkan agar anak tidak merasa dipaksa dan diintimidasi sehingga diharapkan anak tidak mengalami trauma pasca proses penyidikan.

Penyidik dalam hal melakukan penyidikan terhadap anak yang dilaporkan atau diadukan melakukan tindak pidana harus meminta

8 Adriaan W Bedner, dkk., Kajian Sosio-Legal, Denpasar, Pustakan Larasan, 2012.

9 Pasal 19 (1) UU SPPA.

10 Pasal 18 UU SPPA.

11 Pasal 22 UU SPPA. 
pertimbangan atau saran dari Pembimbing Kemasyarakatan, dan apabila perlu juga dapat meminta pertimbangan atau saran dari ahli pendidikan, psikolog, psikiater, tokoh agama, Pekerja Sosial Profesional atau Tenaga Kesejahteraan Sosial, dan tenaga ahli lainnya. Apabila penyidikan dilakukan tanpa melibatkan Pembimbing Kemasyarakatan dari Bali Pemasyarakatan (Bapas) maka penyidik dapat dikenai sanksi administratif. ${ }^{12}$ Bapas dalam waktu 3x24 jam wajib menyerahkan hasil penelitian kemasyarakatan kepada penyidik, hal ini dimaksudkan agar hasil pemeriksaan dalam proses penyidikan sesuai dengan keadaan yang sebenarnya. Berdasarkan hasil Penelitian Kemasyarakatan, Penyidik Anak dapat mempertimbangkan dapat tidaknya berkas perkara/Berita Acara Pemeriksaan (BAP) diteruskan untuk proses penuntutan.

Dalam melakukan upaya pro justitia semisal, penangkapan dan penahanan, penyidik anak pun diberikan batasan yang cukup ketat. Penangkapan misalnya dalam Pasal 3 huruf g UU SPPA menyatakan bahwa seorang anak berhak untuk tidak ditangkap, ditahan, atau dipenjara, kecuali sebagai upaya terakhir dan dalam waktu yang paling singkat. Ketentuan pasal ini jelas menunjukkan bahwa perlindungan hukum yang diberikan terhadap seorang anak yang melakukan tindak pidana tidak wajib untuk ditahan dalam proses peradilan pidana dan walaupun dilakukan penahanan untuk kepentingan penyidikan terhadap anak tersebut, hal tersebut hanyalah sebagai upaya terakhir atau tindakan terakhir (ultimum remedium) dan dalam waktu yang sangat singkat yaitu paling lama 24 (dua puluh empat) jam.

Sedangkan dalam proses penahanan anak, Pasal 32 ayat (1) UU SPPA menentukan bahwa penahanan terhadap anak tidak boleh dilakukan apabila anak tersebut memperoleh jaminan dari orang tua/wali dan /atau lembaga bahwa anak tidak akan melarikan diri, tidak akan menghilangkan atau merusak barang bukti dan/atau tidak mengulangi tindak pidana. Pasal 32 ayat (2) UU SPPA menyatakan bahwa penahanan terhadap Anak hanya dapat dilakukan dengan syarat yang harus dinyatakan secara tegas dalam surat perintah penahanan dan anak yang ditahan telah berumur 14 (empat belas) tahun atau lebih; dan diduga melakukan tindak pidana dengan ancaman pidana penjara 7 (tujuh) tahun atau lebih.

Jangka waktu penahanan bagi anak diajukan oleh instansi yang berwenang di masing-masing tahapan, baik penyidikan, penuntutan dan pemeriksaan di ruang sidang juga dalam tahapan upaya hukum mulai dari banding sampai dengan kasasi, alur jangka waktu penahanan dapat dilihat sebagai berikut:

UU SPPA juga menyebutkan bahwa selama Anak ditahan, kebutuhan jasmani, rohani dan sosial anak harus terpenuhi. Untuk melindungi keamanan Anak, dapat dilakukan penempatan Anak di Lembaga 
Tabel 1. Alur Jangka Waktu Penahanan

\begin{tabular}{|l|l|l|}
\hline \multicolumn{1}{|c|}{ Tahapan } & Penahanan & \multicolumn{1}{c|}{$\begin{array}{c}\text { Perpanjangan } \\
\text { Penahanan }\end{array}$} \\
\hline Penyidikan & 7 hari & 8 hari \\
\hline Penuntutan & 5 hari & 5 hari \\
\hline Persidangan & 10 hari & 15 hari \\
\hline Banding & 10 hari & 15 hari \\
\hline Kasasi & 15 hari & 20 hari \\
\hline Total & $\mathbf{3 7}$ hari & $\mathbf{6 3}$ hari \\
\hline
\end{tabular}

Sumber: Data Sekunder, diolah 2015

Penyelenggaraan Kesejahteraan Sosial (LPKS), sehingga apabila tidak terdapat Lembaga Penempatan Anak Sementara pada daerah dimana Anak ditahan, penahanan dapat dilakukan di LPKS setempat. ${ }^{13}$

Anak yang berkonflik dengan hukum wajib mendapatkan bantuan hukum pada setiap tingkat pemeriksaan dan didampingi oleh Pembimbing Kemasyarakatan atau pendamping lain sesuai dengan ketentuan peraturan perUndang-undangan. ${ }^{14}$ Dalam hal penggunaan upaya paksa, pelanggaran terhadap kewajiban pemberian bantuan hukum ini mengakibatkan penangkapan dan penahanan anak batal demi hukum. Dalam penjelasan pasal 18 jo. Pasal 40 UU SPPA dinyatakan bahwa pemberian bantuan hukum dalam proses peradilan pidana anak selain oleh advokat dapat juga dilakukan oleh paralegal, dosen, mahasiswa hukum yang memenuhi ketentuan UU nomor 16 tahun 2011 tentang bantuan hukum.

\section{B. Kajian tentang Diversi sebagai Implementasi Restorative Justice}

Pentingnya proses diversi disadari oleh pembuat Undang-undang, dalam Pasal 6 UU SPPA disebutkan bahwa tujuan dari Diversi adalah untuk mencapai perdamaian antara korban dan Anak, menyelesaikan perkara Anak di luar proses peradilan, menghindarkan Anak dari perampasan kemerdekaan, mendorong masyarakat untuk berpartisipasi dan menanamkan rasa tanggung jawab kepada Anak. Dengan demikian, dapat terlihat UU SPPA memuat klausula yang mendorong anak-anak tidak perlu menjalani proses pidana dengan tanpa menihilkan penanaman rasa tanggung jawab anak dalam proses diversi.

Proses diversi ini berguna bagi anak yang menghadapi kasus hukum untuk menghindari efek negatif dari proses-proses peradilan selanjutnya dalam administrasi peradilan anak semisal labelisasi atau stigmatisasi akibat pernyataan bersalah maupun vonis hukuman. 
Selain itu, ICJR dalam penelitiannya menyimpulkan bahwa proses diversi ini merupakan salah satu terobosan dalam meminimalisir penggunaan pemidanaan yang sangat berat, karena temuan ICJR memperlihatkan banyak kasus anak yang diancam dengan pidana 7 tahun atau lebih. ${ }^{15}$ Hal ini kemudian bergantung pada pandangan aparat penegak hukum terhadap tindak pidana yang dilakukan anak dan bagaimana mereka memanfaatkan instrumen yang ada dalam UU SPPA. ${ }^{16}$

Pelaksanaan diversi, sebagaimana ditekankan dalam Pasal 8 ayat (1) UU SPPA menggunakan pendekatan restorative justice yaitu dengan cara penyelesaian perkara pidana anak dengan cara musyawarah yang melibatkan Anak dan orang tua/ Walinya, korban dan/atau orang tua/Walinya, Pembimbing Kemasyarakatan, dan Pekerja Sosial Profesional. ${ }^{17}$

Diversi harus dilakukan paling lambat 7 (tujuh) hari setelah penyidikan dimulai. ${ }^{18}$ Diversi sebagaimana dimaksud dalam Pasal 1 angka 7 UU SPPA didefinisikan sebagai pengalihan penyelesaian perkara Anak dari proses peradilan pidana ke proses di luar peradilan pidana. Pengaturan di UU SPPA ini merupakan respon dari celah hukum dalam UU Pengadilan Anak tahun 1997 yang lama. dimana UU tersebut tidak memberikan ruang terhadap kemungkinan pemberian diversi.

Dalam melaksanakan diversi, penyidik wajib memperhatikan kepentingan korban, kesejahteraan dan tanggung jawab Anak, penghindaran stigma negative, penghindaran pembalasan, keharmonisan masyarakat dan kepatutan, kesusilaan, dan ketertiban umum. ${ }^{19}$

Penyidikjuga harus mempertimbangkan kategori tindak pidana, yaitu tindak pidana yang diancam pidana penjara dibawah tujuh tahun, umur Anak, dimana semakin rendah usia anak maka harus lebih didorong upaya Diversi, hasil penelitian kemasyarakatan dari Bapas dan dukungan lingkungan keluarga dan masyarakat.

Selain itu, proses diversi ini hanya dapat dilakukan pleh penyidik terhadap tindak pidana yang diancam dengan pidana penjara di bawah 7 tahun seperti pembunuhan, pemerkosaan, narkotika, terorisme dan tindak pidana lainnya dan bukan merupakan pengulangan tindak pidana.

15 Sufriadi Pinim Erasmus A. T. Napitupulu, Studi Atas Praktik Peradilan Anak di Jakarta, Institute for Criminal Justice Reform, 2013, hlm. 29.

16 Ibid., hlm. 66.

17 Penjelasan Umum UU SPPA menyebutkan bahwa "Restoratif justice merupakan suatu proses Diversi, yaitu semua pihak yang terlibat dalam suatu tindak pidana tertentu bersama-sama mengatasi masalah serta menciptakan suatu kewajiban untuk membuat segala sesuatunya menjadi lebih baik dengan melibatkan korban, Anak, dan masyarakat dalam mencari solusi untuk memperbaiki, rekonsiliasi, dan menenteramkan hati yang tidak berdasarkan pembalasan. Proses peradilan perkara Anak sejak ditangkap, ditahan, dan diadili pembinaannya wajib dilakukan oleh pejabat khusus yang memahami masalah Anak. Namun, sebelum masuk proses peradilan, para penegak hukum, keluarga, dan masyarakat wajib mengupayakan proses penyelesaian di luar jalur pengadilan, yakni melalui Diversi berdasarkan pendekatan Restoratif justice.

18 Pasal 29 (1) UU SPPA.

19 Pasal 8 ayat (3) UU SPPA. 
Kepentingan korban juga harus pidana tanpa korban; atau nilai kerugian diperhatikan dalam proses diversi, jika korban tidak lebih dari nilai upah minimum korban menolak, maka kesepakatan diversi provinsi setempat, proses diversi tidak perlu tidak bisa tercapai, dengan kata lain posisi tersangka atau terdakwa anak ada di posisi tawar yang lemah bergantung pada kesediaan korban untuk melakukan pemaafan. Hasil kesepakatan Diversi dapat berbentuk, antara lain: perdamaian dengan atau tanpa ganti kerugian; penyerahan kembali kepada orang tua/Wali; keikutsertaan dalam pendidikan atau pelatihan di lembaga pendidikan atau LPKS paling lama 3 (tiga) bulan; atau pelayanan masyarakat.

Kecuali untuk tindak pidana yang berupa pelanggaran; tindak pidana ringan; tindak mempertimbangkan kepentingan korban. Penyidik cukup melakukan diversi dengan melibatkan pelaku dan/atau keluarganya, Pembimbing Kemasyarakatan, serta dapat melibatkan tokoh masyarakat. Bentuk keputusan diversi yang bisa diputuskan oleh penyidik antara lain; pengembalian kerugian dalam hal ada korban; rehabilitasi medis dan psikososial; penyerahan kembali kepada orang tua/Wali; keikutsertaan dalam pendidikan atau pelatihan di lembaga pendidikan atau LPKS paling lama 3 (tiga) bulan; atau pelayanan masyarakat paling lama 3 (tiga) bulan.

\section{Bagan 1. Bagan Proses Diversi dalam Tahap Penyidikan Berdasarkan UU SPPA}

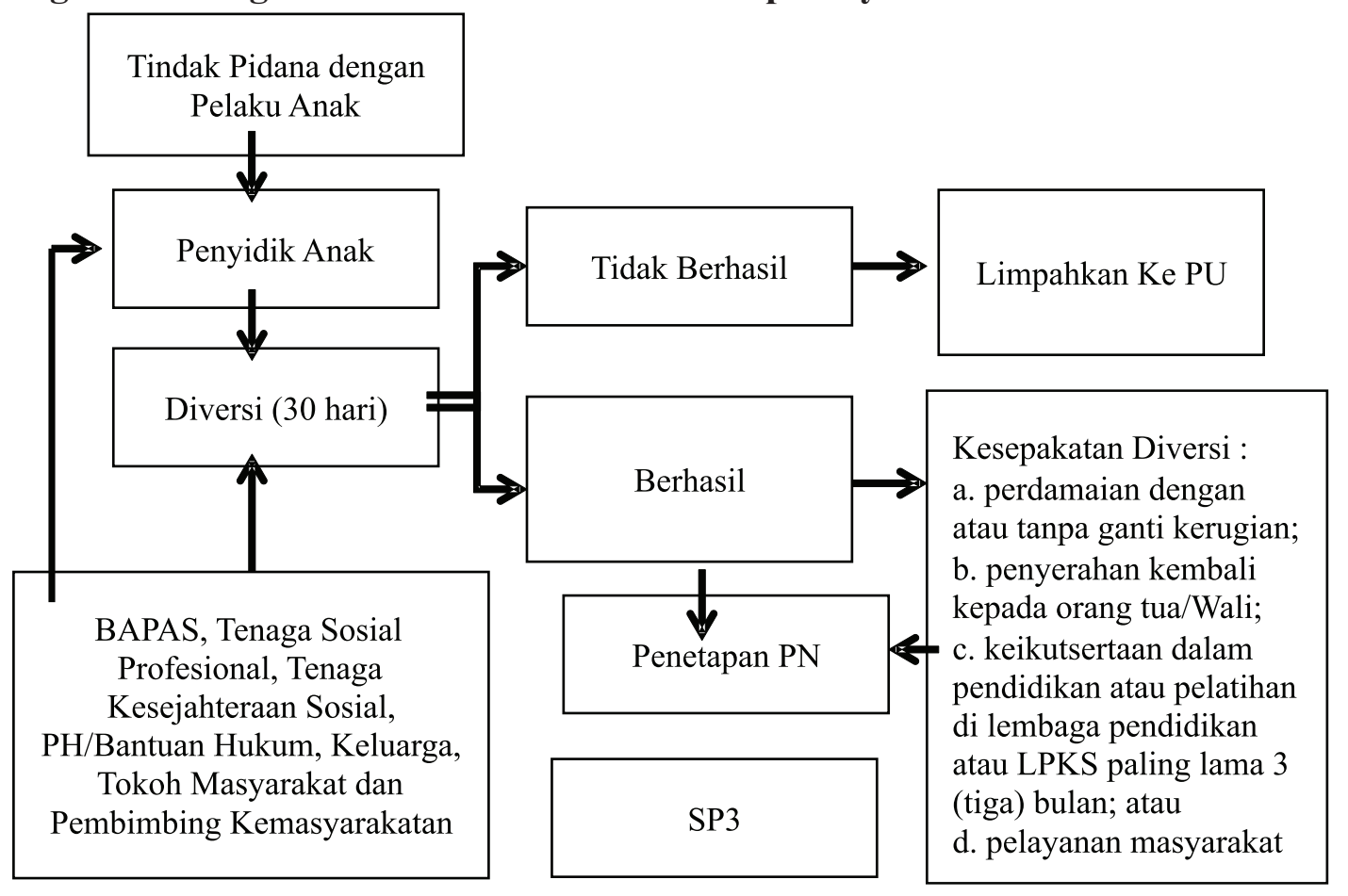

\section{Sumber: Data Sekunder, diolah dari UU SPPA}


Setidaknya, menurut Koesno Adi, diversi akan menjadi lebih bermanfaat jika dilakukan sejak tahapan penyidikan, hal ini dikarenakan: ${ }^{20}$

1. Kepolisian merupakan satu-satunya lembaga penegak hukum dalam subsistem peradilan pidana yang mempunyai jaringan hingga tingkat kecamatan. Dengan demikian, secara structural lembaga kepolisian merupakan satusatunyalembaga penegak hukum yang paling dekat dan paling mudahdijangkau oleh masyarakat. Dengan potret kelembagaan yang demikian, kepolisian merupakan lembaga penegak hukum yang paling memungkinkan untuk memiliki jaringan sampai di tingkat yang paling bawah (tingkat desa). Salah satu lembaga yang dibentuk oleh kepolisian pada tingkat desa/kelurahan adalah Badan Kemitraan Polisi dan Masyarakat (BKPM).

2. Secara kuantitas aparat kepolisian jauh lebih banyak dibandingakan denganaparat penegak hukum yang lainnya, sekalipun juga disadari bahwa tidaksetiap aparat kepolisian mempunyai komitmen untuk menangani tindakpidana yang dilakukan oleh anak, tetapi ketersediaan personil yang cukupmemadai juga akan sangat membantu proses penyelesaian tindak pidana yangdilakukan oleh anak.

3. Oleh karena lembaga kepolisian merupakan aparat penegak hukum pertamayang bergerak dalam proses peradilan pidana, maka diversi di tingkatkepolisian mempunyai makna memberikan jaminan kepada anak untuk sedinimungkin dihindarkan dari bersinggungan dengan proses peradilan pidana.Dengan demikian, dampak negatif akibat anak bersinggungan dengan aparatpenegak hukum dapat diminimalisir.

Mengingat pentingnya peran kepolisian dalam proses diversi, maka penguatan peran Kepolisian sebagai pintu masuk ke peradilan pidana harus dilakukan. UU SPPA mengatur tahapan proses diversi di tahapan penyidikan sebagai berikut:

\section{Implementasi Diversi dalam Kasus Pidana dengan Pelaku Anak di Kepolisian Resort Malang}

Undang-undang Nomor 11 tahun 2012 tentang Sistem Peradilan Pidana Anak (UU SPPA) memberikan perlakuan istimewa terhadap anak yang berkonflik dengan hukum sejak dari proses penyidikan. Sebagai ujung tombak dalam pelaksanaan peradilan anak, aparat kepolisian harus memberikan perhatian dan perlakuan khusus kepada anak yang berkonflik dengan hukum agar anak tidak menjadi korban dari penerapan prosedur hukum yang rigid dan formal.

Pada tahap penyelidikan dan penyidikan di kepolisan, pendekatan restorative justice dapat digunakan dan dioptimalkan berdasarkan kewenangan diskresi (discretionary powers). Dalam konsep hukum administrasi Negara, kewenangan diskresi adalah salah satu sarana yang memberi ruang gerak bagi pejabat atau badan-badan administrasi negara untuk melakukan tindakan tanpa harus terikat sepenuhnya pada Undang-undang.

20 Koesno Adi, Diversi Sebagai Upaya Alternatif Penanggulangan Tindak Pidana Narkotika oleh Anak, UMM Press, Malang, 2009, hlm. 112-113. 
Kewenangan diskresi diberikan kepada pemerintah (jajaran badan-badan administrasi negara) mengingat fungsi pemerintah / administrasi negara, yaitu menyelenggarakan kesejahteraan umum. ${ }^{21}$

Aparatur penyidik yang menangani perkara dengan pelaku anak di kepolisian Resort Malang merupakan penyidik khusus yang menangani kasus anak dan telah mengikuti pelatihan khusus tentang bagaimana melakukan penyidikan kasus anak. ${ }^{22}$

Proses penyidikan kasus anak di Unit SPPA berusaha dilakukan secara simpatik dengan mengedepankan suasana kekeluargaan. ${ }^{23}$ Selain juga penyidik menggunakan pakaian sipil, ${ }^{24}$ dengan maksud agar anak tidak merasa terintimidasi selama proses penyidikan.

Penyidik Polres malang juga berkoodinasi dengan Pembimbing Kemasyarakatan Balai Pemasyarakatan (Bapas) dalam hal hasil penelitian kemasyarakatan anak yang diwajibkan dalam UU SPPA. Polres Malang telah memiliki MoU dengan Bapas, sehingga jangka waktu yang ditentukan oleh UU SPPA tidak sampai terlampaui.

Sedangkan dalam proses penahanan anak, sesuai Pasal 32 ayat (1) UU SPPA, selama anak memperoleh jaminan dari orang tua/wali dan /atau lembaga bahwa anak tidak akan melarikan diri, tidak akan menghilangkan atau merusak barang bukti dan/atau tidak mengulangi tindak pidana, penyidik Polres Malang tidak melakukan penahanan.

Selanjutnya terkait kebijakan penyidik terhadap penanganan kasus tindak pidana anak, Pasal 18 Undang-undang nomor 2 tentang Kepolisian menjadi dasar bagi tindakan diskresi yang diambil oleh penyidik kepolisian dimana dinyatakan bahwa untuk kepentingan umum pejabat kepolisiannegara republik indonesia dalammelaksanakan tugas dan wewenangnya dapat bertindak menurut penilaiannya sendiri (diskresi). Dan dalam melaksanakan diskresi tersebut hanya dapat dilakukan dalam keadaan yang sangat perlu dengan memperhatikan peraturan perundangundangan, serta kode etik profesi kepolisian negara republik Indonesia.

Tidak adanya batasan rumusan unsur dan kriteria dalam penggunaan diskresi kepolisian menjadikan penggunaan diskresi rawan disalah gunakan. Baik-buruknya keputusan diskresi ditentukan oleh prilaku oleh anggota kepolisian. Oleh karenanya penilaian yang diambil dalam pengambilan keputusan diskresi harus didasarkan pada asas-asas umum pemerintahan umum yang baik (algemene beginselen van behorlijk bestuur) dan bertumpu pada konsep Good Governance. $^{25}$ 
Menurut data yang diperoleh peneliti dari Kepolisian Resort Malang (Polres Malang), jenis kasus pidana dengan pelaku anak yang sering ditangani selama ini antara lain kasus pencurian (pasal 362 dan 363 KUHP), penggelapan(pasal378 KUHP), pengeroyokan (pasal 170 KUHP), penganiayaan (pasal 351 KUHP), persetubuhan anak (pasal $81 \mathrm{UU}$ 22/2003 tentang perlindungan anak). ${ }^{26}$

Khusus sampai bulan September 2014, dari berbagai macam kasus di atas tercatat baru dua kasus dengan pelaku anak yang mengikuti prosedur sebagaimana diatur dalam UU SPPA, ${ }^{27}$ yaitu kasus pembunuhan di Singosari dan di Tajinan. Kedua kasus ini tidak dapat dikenakan proses diversi karena ancaman hukumannya di atas 7 (tujuh) tahun.

Sebelum pemberlakuan UU SPPA, Polres Malang telah menerapkan diversi dengan berpedoman pada Telegram Rahasia Kabareskrim Polri Nomor: TR/1124/ IX/2006. Bentuk diversi yang dilaksanakan di Kepolisian Resort Malang adalah menghentikan proses penyidikan, kemudian mewajibkan pelaku untuk melakukan wajib lapor tiap hari senin dan kamis selama 2 (dua) bulan. Hal ini dilakukan sebagai bentuk shock therapy kepada pelaku dan sekaligus sebagai model pengawasan terhadap anak yang berkonflik dengan hukum.

Mekanisme Diversi yang dilaksanakan oleh dengan memfasilitasi perdamaian antara korban atau keluarganya dan pelaku atau keluarganya, jika telah dicapai kesepakatan perdamaian diantara kedua belah pihak selanjutnya pihak korban akan mencabut laporan polisi dan dibuat surat kesepakatan perdamaian dimana surat tersebut akan dimintakan penetapan kepada Kapolres melalui gelar perkara.

Terkait dengan impelementasi diversi dalam UU SPPA, Polres Malang hingga saat ini hanya siap jika hasil diversi sebagaimana diatur dalam pasal 11 UU SPPA berupa perdamaian dan penyerahan kembali ke orang tua/wali. Bentuk diversi yang diterapkan hanya wajib lapor bagi pelaku setiap hari senin dan kamis, meski ada usaha untuk melibatkan Kepala Desa dalam hal ADR dan pengawasan pelaku anak di desa tempat tinggalnya, dan pengawasan di sekolah kerja sama dengan Dinas Pendidikan (Sekolah Umum) dan Kementerian Agama (Madrasah). ${ }^{28}$ Bentuk diversi lain seperti kerja sosial dan pendidikan/ pelatihan sebagaimana diatur dalam pasal 11 UU SPPA hingga saat ini masih dalam tahap

26 Data diolah dari dokumen perkara masuk di Unit PPA Polres Malang tahun 2014.

27 Hal ini dikarenakan UU SPPA baru saja berlaku per tanggal 31 Juli 2014.

28 Wawancara dengan Sutiyo, SH., M.Hum, Kanit PPA Polres Malang, 2 September 2014. 
perumusan dengan dinas sosial Pemerintah Kabupaten Malang dan Pusat Pelayanan Terpadu Pemberdayaan Perempuan Dan Anak (P2TP2A). ${ }^{29}$

Keterbatasan bentuk diversi yang diterapkan oleh Kepolisian Resort Malang dimana hanya dalam bentuk pengembalian kepada orang tua menjadikan proses diversi yang ditawarkan kepada korban bisa terancam gagal. Hal ini dikarenakan, bentuk diversi berupa pengembalian kepada orang tua merupakan proses terlemah dengan tidak ada proses pendidikan yang dilakukan terhadap pelaku tindak pidana anak seperti pendidikan atau kerja sosial. Kemungkinan penolakan dari keluarga korban menjadi sangat besar karena ketidak mampuan penyidik untuk meyakinkan korban bahwa pelaku akan dididik dengan baik dan tidak akan mengulangi tindak pidana di masa mendatang.

\section{Problematika Penerapan Diversi dalam Kasus Pidana dengan Pelaku Anak di Kepolisian Resort Malang}

Polres Malang mengakui bahwa prosedur dan mekanisme diversi yang diamanatkan dalam UU SPPA belum terlaksana dengan baik, selain karena belum adanya Peraturan Pemerintah yang mengatur tentang teknis pelaksanaan diversi, ${ }^{30}$ juga karena belum adanya kesepahaman di antara aparat penegak hukum dan pemerintah daerah. ${ }^{31}$

Selain itu, berdasarkan angket yang penulis edarkan kepada beberapa penyidik Unit PPA di Kepolisian Resort di Jawa Timur termasuk Polres Malang, ${ }^{32}$ masalah utama yang mengemuka adalah tidak adanya infrastruktur yang mendukung pelaksanaan UU SPPA. Problem lain secara internal prosedur teknis penyidik kepolisian yang biasanya berupa SKEP (Surat Keputusan Kapolri) tentang implementasi UU SPPA juga kurang tersosialisasi dengan baik, hal yang berakibat pada proses penyidikan kasus anak di masing-masing kepolisian resort tidak seragam.

Khusus di Kabupaten Malang, beberápa infrastruktur untuk menunjang UU SPPA juga belum ada, semisal Lembaga Pembinaan Anak Sementara (LPAS) dan Lembaga Pembinaan Khusus Anak (LPKA), hal ini membuat proses penyidikan terancam batal demi hukum. Minimnya tenaga di Balai Pemasyarakatan (Bapas) juga menjadi masalah, padahal

29 P2TP2A yang merupakan lembaga pelayanan pemberdayaan perempuan dan perlindungan anak berbasis masyarakat yang dibentuk berdasarkan Peraturan Bupati Malang Nomor 8 Tahun 2011. Lembaga ini beranggotakan multi stakeholders dari Pemerintah dan Non Pemerintah (Perguruan Tinggi, Penegak hukum/ Polisi dan Jaksa, Lembaga Swadaya Masyarakat, Kelompok Pemerhati Perempuan dan Anak, dan sebagainya). Lembaga ini dipimpin oleh Sekretaris Daerah Kabupaten Malang dan menyelenggarakan koordinasi rutin setiap 3 bulan sekali untuk membahas isu-isu tentang anak dan perempuan di wilayah Kabupaten Malang. Salah satu hasil dari adanya koordinasi dengan P2TP2 adalah dukungan APBD berupa anggaran khusus yang disediakan oleh pemerintah kabupaten untuk memberikan layanan gratis pada visum korban anak.

30 Hukum Online, MA Berharap PP Diversi Segera Terbit, http://www.hukumonline.com/berita/baca/ 1t540036e7e328c/ma-berharap-pp-diversi-segera-terbit, diakses 1 November 2014 pukul 19.32 WIB.

31 Wawancara dengan Sutiyo, SH., M.Hum, Kanit PPA Polres Malang, 2 September 2014.

32 Angket (terlampir) diedarkan pada saat workshop penyidik Anak tentang diversi di FH UB, 20 Agustus 2014. 
dalam pelaksanaan diversi sebagaimana ditekankan dalam Pasal 8 ayat (1) UU SPPA penyelesaian perkara pidana anak dengan cara musyawarah selain melibatkan Anak dan orang tua/Walinya, korban dan/atau orang tua/Walinya juga harus mengikutsertakan pembimbing kemasyarakatan, dan Pekerja Sosial Profesional. Menurut Polres Malang meski pihaknya sudah menggandeng Balai Pemasyarakatan (Bapas), namun jumlah pembimbing kemasyarakatanyang minim membuat proses diversi dikuatirkan menjadi lebih lama daripada yang ditentukan oleh $\mathrm{UU} .{ }^{33}$

Secara eksternal, mayoritas masyarakat terutama keluarga korban yang memandang bahwa anak yang berkonflik dengan hukum pun harus dihukum setimpal layaknya orang dewasa. Hal ini diakui oleh beberapa penyidik yang kesulitan dalam melakukan proses perdamaian terhadap kasus anak karena kuatnya pengaruh keluarga korban yang menentang proses diversi.

Terkait dengan anak yang yang dilaporkan melakukan tindak pidana, dimana penyidik wajib merahasiakan identitas sang anak baik dari pemberitaan di media cetak maupun di media elektronik, ${ }^{34}$ diakui sulit sekali dilaksanakan. Kuatnya pengaruh media massa dan agresivitas wartawan dalam mencari berita terkait kasus anak dengan alasan UU Keterbukaan Informasi Publik pun menjadikan hampir semua kasus dengan pelaku anak terpampang di koran setempat. Hal yang berakibat pada sulitnya memulai proses diversi karena stigma yang sudah terlanjur melekat pada anak pelaku tindak pidana. ${ }^{35}$

\section{E. Langkah Strategis Penyidik} Kepolisian Resort Malang dalam Mengatasi Problem yang Muncul Terkait dengan Pemberlakuan Diversi dalam UU SPPA

Sebagaimana telah dibahas di muka, keberadaan P2TP2A di Kabupaten Malang yang dikoordinatori oleh Sekretaris Daerah diakui sangat membantu menyelesaikan beberapaproblemayang timbulatas berlakunya UU SPPA. Sebagaimana dituturkan oleh Kanit PPA Polres Malang dalam fórum tersebut sudah mulai dibicarakan kemungkinankemungkinan penanganan anak pelaku tindak pidana oleh P2TP2A Kabupaten Malang. Saat ini Dinas Sosial sebagai salah satu unsur P2TP2A Kabupaten Malang sedang mencari model diversi berupa pelayanan masyarakat yang disesuaikan dengan karakteristik kabupaten Malang semisal dengan melibatkan anak yang didiversi kepada kegiatan-kegiatan yang berhubungan dengan sosial keagamaan

33 Hal yang berpengaruh juga pada proses penyidikan dimana dalam waktu paling lama 3 (tiga) hari penyidik wajib mendapatkan hasil Penelitian Masyarakat/Litmas dari BAPAS membuat penyidik kuatir proses penyidikannya menjadi batal demi hukum.

34 Pasal 19 (1) UU SPPA.

35 Wawancara dengan Sutiyo, SH., M.Hum, Kanit PPA Polres Malang, 2 September 2014. 
dengan menggandeng organisasi masyarakat yang peduli dengan isu anak. ${ }^{36}$

Permasalahan ketiadaan dengan LPAS atau LPKS sebagaimana diamanatkan dalam UU SPPA dalam proses penahanan, dicoba diselesaikan secara procedural adminsitratif dengan berkirim surat kepada Pihak Dinas Sosial Kabupaten Malang (terlampir) terkait prosedur penahanan kasus pidana dengan pelaku anak, Dinas Sosial selamjutnya melalui balasan suratnya menitipkan tahanan anak yang menjadi yurisdiksinya ke tahanan khusus anak yang dimiliki oleh Polres Malang. Hal ini diakui oleh penyidik Polres Malang sebagai antisipasi adanya gugatan pra-peradilan dari tersangka anak terkait ketidak sesuaian prosedur hukum acara sebagaimana diamanatkan dalam UU SPPA.

Pelibatan masyarakat dalam proses diversi sebagaimana diatur dalam pasal 93 UU SPPA yang menyatakan bahwa Masyarakat dapat berperan serta dalam pelindungan Anak mulai dari pencegahan sampai dengan reintegrasi sosial Anak dengan cara:

a. menyampaikan laporan terjadinya pelanggaran hak Anak kepada pihak yang berwenang;

b. mengajukan usulan mengenai perumusan dan kebijakan yang berkaitan dengan Anak;

c. melakukan penelitian dan pendidikan mengenai Anak;

d. berpartisipasi dalam penyelesaian perkara
Anak melalui Diversi dan pendekatan Keadilan Restoratif;

e. berkontribusi dalam rehabilitasi dan reintegrasi sosial Anak, Anak Korban dan/atau Anak Saksi melalui organisasi kemasyarakatan;

f. melakukan pemantauan terhadap kinerja aparat penegak hukum dalam penanganan perkara Anak; atau

g. melakukan sosialisasi mengenai hak Anak serta peraturan perUndangundangan yang berkaitan dengan Anak.

Kesemua hal tersebut diatas sedang dicarikan formulasinya dengan melakukan sosialisasi dan penguatan kerja sama dengan organisasi kemasyarakatan dan unsur Muspida (Musyawarah pimpinan Daerah) agar ke depan implementasi dari diversi benar-benar sesuai dengan semangat restorative justice dengan tidak menghilangkan unsur kearifan lokal

\section{Simpulan}

Impelementasi diversi dalam UU SPPA di Polres Malang hingga saat ini belum maksimal karena kemampuan penyidik untuk menawarkan bentuk diversi hanya berbentuk perdamaian dan penyerahan kembali ke orang tua/wali. Bentuk diversi yang diterapkan hanya wajib lapor bagi pelaku setiap hari senin dan kamis, meski ada usaha untuk melibatkan Kepala Desa dalam hal ADR dan pengawasan pelaku anak di desa tempat tinggalnya, dan 
pengawasan di sekolah kerja sama dengan Dinas Pendidikan (Sekolah Umum) dan Kementerian Agama (Madrasah). Bentuk diversi lain seperti kerja sosial dan pendidikan/ pelatihan sebagaimana diatur dalam pasal 11 UU SPPA hingga saat ini masih dalam tahap perumusan dengan dinas sosial Pemerintah Kabupaten Malang dan Pusat Pelayanan Terpadu Pemberdayaan Perempuan Dan Anak (P2TP2A).

Ketidak optimalan ini antara lain disebabkan karena belum adanya Peraturan Pemerintah yang mengatur tentang teknis pelaksanaan diversi dan sampai saat ini belum terbentuk infrastruktur/ lembaga yang diamanatkan dalam UU SPPA di Kabupaten Malang
Untuk mengatasi ketidak optimalan tersebut di atas, langkah-langkah strategis yang dilakukan oleh Polres Malang antara lain memanfaatkan forum P2TP2A Kabupaten Malang untuk mencari model diversi berupa pelayanan masyarakat yang disesuaikan dengan karakteristik kabupaten Malang. Selain itu saat penelitian ini sedang ditulis, sedang coba dirumuskan model pelibatan masyarakat dalam proses diversi sebagaimana diatur dalam pasal 93 UU SPPA dengan melakukan sosialisasi dan penguatan kerja sama dengan organisasi kemasyarakatan dan unsur Forpimda (Forum pimpinan Daerah) .

\section{DAFTAR PUSTAKA}

\section{Buku}

Adriaan W Bedner, dkk., 2012, Kajian Sosio-

Legal, Pustakan Larasan, Denpasar, Johnny Ibrahim, Teori danMetodologi Penelitian Hukum Normatif, Bayumedia, Malang.

Koeno Adi, 2009, Diversi Sebagai Upaya Alternatif Penanggulangan Tindak Pidana Narkotika Oleh Anak, UMM Press, Malang.

Sufriadi Pinim \& Erasmus Napitupulu, 2013,

Studi atas Praktik-praktik Peradilan Anak di Jakarta, Institute for Criminal Justice Reform, Jakarta.

Taufik Makarao, 2013, Pengkajian Hukum

Tentang Penerapan Restorative
Justice Dalam Penyelesaian Tindak Pidana Yang Dilakukan Oleh AnakAnak, Badan Pembinaan Hukum Nasional, Jakarta.

\section{Jurnal}

Yutirsa Yunus, Analisa Konsep Restorative Justice Melalui Sistem Diversi dalam Sistem Peradilan Pidana Anak di Indonesia, Jurnal Rechtsvinding, Volume 2 No. 2, Agustus 2013.

\section{Makalah}

Nurini Aprilianda, Fachrizal Afandi, Joko Purnomo, Laporan Penelitian Hibah Bersaing Institusi Batch II 2012, Desain 
Pelembagaan Diversi Dalam Perkara

Anak Berbasis Social Responsibility

(Studi Pada Tiga Kepolisian Resort

Kota/Kabupaten di Jawa Timur)

Tidak dipublikasikan.

\section{Peraturan Perundang-undangan}

Undang-undang Nomor 11 Tahun 2012 tentang Sistem Peradilan Pidana Anak.

\section{Naskah Internet}

Barry Goldson and John Muncie, Rethinking Youth Justice: Comparative Analysis,
International Human Rights and

Research Evidence, 2006, http://yjj. sagepub.com/content/6/2/91.refs.html. Hukum Online, MA Berharap PP Diversi Segera Terbit, http://www. hukumonline.com/berita/baca/ 1t540036e7e328c/ma-berharap-ppdiversi-segera-terbit.

Sinar Harapan, Pemerintah Dinilai Abaikan Kepentingan Anak, http:// sinarharapan.co/news/read/140616047/ Pemerintah-Dinilai-AbaikanKepentingan-Anak. 